\title{
LEARNING FROM OTHERS, LEARNING WITH OTHERS: THE TENSE ENCOUNTER BETWEEN EQUALITY AND DIFFERENCE
}

\author{
FRANCESCA GOBBO \\ University of Turin, Italy \\ "Plurality means acknowledging others, \\ and listening seriously to them"
}

(Griffiths, 2003)

\begin{abstract}
After pointing out how individuals' relational dimension, and thus personal and collective differences, have been positively recognized by multicultural and intercultural during the last forty years, the author stresses that educational processes and policies are still interrogated by learners' unequal status and opportunities. She then explores the areas of research, theory and practice (such as comparativeeducation, cooperative learning, ethnography and cultural anthropology) that recognize how the educational and socio-cultural importance of relating to, and learning from, others and with others can respond to issues of equity and social justice.
\end{abstract}

Keywords:other/otherness;comparativeeducation;cooperativelearning;intercultural education; ethnography.

\section{Introduction}

Acknowledging others' diversity - be it ethnic, cultural, religious, sexual or physical - as well as their common humanity has characterized Western educational thought for at least the past forty years. Today, multiculturalism is too often used as a descriptive concept that allows social researchers and educators to refer conveniently to the increasingly complex and heterogeneous fabric of societies, but in fact it emerged and grew from the political demand of minority citizens for self determination and for recognition of the value of diversity, a demand originally representing a way of attaining social justice whose meaning, and reach, was thus extended beyond equal opportunity and access to education (Gobbo, 1977).

The awareness that others have the right to be acknowledged, and that attention must be paid to what they say, had historically and politically been anticipated by those others' self-acknowledgment of their otherness, and by the fact that they had succeeded in making their voice heard. These moves spurred lasting and heated debates in countries such as the United States (see Berube, 1994; Gobbo, 1992), but with regard to education they emphasized the specific aspects the relational dimension consists of: for one thing, who one is and will become cannot be conceptualized outside of what one is - her/his plural memberships in society. For 
the other, "having a say is learned in a relationship with or against others" (Griffiths, 2003, p. 35).

As Griffiths states it, education is "to choose to work with other people" (idem, p. 96), a point that the Latin etymology of the verb "to educate" had expressed in terms of the "act of drawing out". According to a first interpretation, the educator's task is to draw or bring out what interests or potential are within the young person, and then foster his/her growth by providing him/her with opportunities to make sense, reflect and act. According to a second interpretation, the educator's task is more similar to that of the pedagogue, namely to lead the young person where knowledge is imparted or to those who can impart it ${ }^{1}$. Education cannot be pursued without the intervention of others: even when we speak of someone committed to educate him/herself (as in the case of Sartre's character of the self-taught man in La nausée), we must imagine a person that becomes responsible for, and supports in different ways, his/her eagerness to know, or to do, after having acknowledged his/ her own desire or need as another person would.

We learn from others continuously: because as human beings we are endowed with very few innate capacities, every newborn must be involved in a very early process of education. Thanks to this, it will slowly learn all that is deemed cognitively and emotionally important for participating competently in the way of life that parents, relatives and neighbours already share and have informally been passing on to it. Later on, schooling will engage others in the task of purposely transmitting both disciplinary contents and social knowledge, while young people, in turn, will seek to find answers to their own questions by themselves and set out to explore contexts and relations that are not yet part of their everyday life and culture, or that can no longer be taken for granted - as anthropologists would specify.

Yet schooling itself can be a hard experience, because social and cultural inequalities are more often confirmed in the classroom than interpreted and confronted with solutions. On the one hand, social stratification does influence the very process of learning and the degree and quality of things learned in different ways (Goodenough, 1976; Ogbu, 1996; Wolcott, 1996) as does the experience of migration and the discontinuity between the "little traditions" learned at home and within the community (Wax \& Wax, 1971) and the mainstream (and majority) culture. On the other hand, the organizational, educational and cultural principles to which schools refer to, and which they enact, have increasingly attracted researchers' close and critical attention (see for instance, Florio-Ruane, 1996; van Zanten 1996, 2003; van Zanten, 2000; Gobbo, 2000; Piasere, 2004, 2007; Saletti Salza 2003, 2004, 2007, 2008; Sidoti, 2007) for the negative effects they can have on minority pupils and students. My ethnographic research among the fairground and circus people in an area of the Veneto region, in the North East of Italy, represents a truly instructive vantage point from which to understand the subtle ways in which

1 In both cases, the responsibility for the intentional action of educating young persons is traditionally assigned to adults, though contemporary educational thought would certainly recognize that young people can also transmit knowledge to their peers effectively and even introduce adults to their own views. 
the right to education is not realized, or realized in a do-it-yourself fashion which is not available to everyone, and that certainly cannot be the means by which the right to education may be upheld (Gobbo, 2003, 2006, 2007a, 2007b).

\section{Reflecting on the others}

It seems appropriate, at this point, to consider who are the others from whom, and with whom, we learn. If again we take etymology as a starting point, we find that the word offers a suggestive, though not conclusive, indication: the other is one of two people, one facing another, and the two make a pair where they can also be in opposition to one another. The inherent connection between the one and the other is thus established, though there is no guarantee that this inextricable relation will be acknowledged and accepted in a positive vein, as history teaches us. The other wears, or has been made to wear, the masks of the outsider, the alien, the foreigner, the stranger, the guest, even that of the scapegoat. Nobel Prize winner Coetzee's novel Waiting for the Barbarians (1980) illustrates vividly and dramatically the unjust enforcement of otherness onto others.

Each of those figures is logically tied to its opposite: so the outsider reclaims the insider, the alien the native, the foreigner and the stranger the family or the familiar, the guest his or her host. Spatial distance, birth rights (especially when they are based on the jus sanguinis), family, community and the feelings they entail (see Benveniste, 1976) provide the various rationales for the pairing connection. What connects each pair is also what divides it. The border lines between the one and the other can be the geo-political ones that are signalled by national frontier posts and guards (thus making those who cross the borders against the rules into trespassers and illegal presences). However, such lines run also through everyday life: the natives' cultural ways are different from, or opposite to, the others' ways which are other. Imagining national identities (Anderson, 1996) has favoured the belief that the attained national borders in fact defined and protected a relatively homogeneous entity, sanctioned by history, language and culture, to which schooling has provided a crucial contribution.

In recent years, cultural anthropology itself has been indicted for having constructed cultural and ethnic identities as metaphorical islands, surrounded by outsiders, marginal people, and foreigners. We owe it to Frederick Barth (1969) if forty years ago he deconstructed (as today we are wont to say) such an image, by giving empirical evidence that the geo-political borders had to be distinguished from the symbolic ones: the latter may differentiate cultural identities just as the former do, but they can also be reinvented by being metaphorically moved and redrawn.

On the basis of my own ethnographic research, I would say that symbolic borders are a matter of mutual (and not necessarily friendly) perception that also depends on the type of, or reasons for, social contacts. Thus, the Veneto fairground and circus people whom I studied between 1999 and 2001 claimed that their occupational nomadism made them to be perceived as others by the sedentary residents of 
towns and villages that periodically host fairs and these occupational nomads (Gobbo, 2003, 2006, 2007a, 2007b). With time, and their communication abilities, those travelling families succeed in making themselves trusted and appreciated by their periodic hosts. The latter's diffidence is generated by the unfamiliar presence represented by fairground and circus people: by definition, nomadic people can stay in a place only for a short time so that they do not fit the order of a sedentary society whose maintenance - as Michael Herzfeld recently reminded us (2006, p. 265 ) - is "both a practical and conceptual task. At the conceptual level it starts with the question 'who is to define the order?', namely 'who is to define the borders?'. It is a question of classification", so that - continues the anthropologist - "people who move 'without a fixed residence' contaminates bureaucracy", and are thus perceived as "out of place" - a perception that is often shared by them also (Gobbo, 2007b, 2008).

As I remarked, "whenever we speak of individuals or groups who are marginal or have been marginalised with respect to the rest of society, we usually imply conditions of social injustice and exclusion, if not of segregation, and a serious difficulty, if not an impossibility, for those people to make their voice heard, their stories listened to" (Gobbo, 2006, p.790)2. Thus, when the travelling families are contrasted with their urban co-citizens, their "otherness" appears the result of a complex, socially constructed and ritualized web of relations that is also subject to temporal and individual variability. With particular regard to the right to education, I have come to the conclusion that "the educational inequality their children suffer does not depend on the sociological and historical traits of a given problematic context (...) but on the disquieting exception that occupational nomadism is perceived to represent for the dominant sedentary lifestyle and for schools" (Gobbo, 2007b, p. 483; see also European Commission, 1994; Ecotec, 2008).

On the contrary, anthropologists have always considered other people, and other cultures as indispensable for an understanding of humankind. Furthermore, very early in time they recognized that "this kind of comprehension is only possible when the investigator moves, usually literally as well as metaphorically, out of his own culture into the unfamiliar one which he wishes to understand and 'learns' the new culture as he would learn a new language" (Beattie, 1964, p.x). In ethnography, "being there" is indispensable not only for the continuing construction of anthropological knowledge, but also for opening up individuals' perspectives

2 However I also added that the view from the margins, and the knowledge and skills it entails, is quite different from that of the outsider: "while marginality means that a person, a location or an activity is not in a central position and therefore, by extension, is of little importance, influence or weight (metaphorically speaking), that person, location or activity is nevertheless logically and symbolically connected to the centre - however defined - by the fact of representing its boundary or boundary area. Thus, staying at the margins of a society, of material and symbolic production, of cultural and occupational opportunities does not prevent such "spatially mobile groups" from having recurrent, usually brief, contacts with sedentary populations (as even prehistorical and classical records indicate), and "today, as in millennia past, children look forward to the periodic visits of carnivals, puppet shows, jugglers and storytellers" (Berland \& Salo, 1986)" (Gobbo, 2006, p. 790) 
and prospects. When there is "only one looking glass, you never discover you are a prisoner of its refraction. The only way to recognize that is to look into a different mirror, one which deforms reality in another way. Only then can you see that you've had a point of view all along" (Bohannan, 1998, p. 7).

In this sense, disciplinary and educational goals appear as strictly interrelated: by interpreting fieldwork as an opportunity to learn - from others and with others - how one's view of things and people has been shaped by received and often unexamined beliefs and values, a major educational aim is set, and hopefully reached, namely that of questioning and overcoming a parochial vision too often at the roots of prejudices, and of racism. Fieldwork is a different way of learning from others (and with others, as I shall illustrate), and has its reason in the recognition of a positive value to otherness, diversity, difference that, albeit not synonymous terms, are today all used to refer to, and to stress, the many changes characterizing our societies, and the different approach they promote in education. Migratory flows have brought not only manpower but also men and women whose different languages, religions, beliefs and cultural traits which the native or autochthonous citizens are invited to pay attention to, valorize and respect.

\section{"Learning from others" and intercultural education: with particular reference to Italy}

In intercultural education, others' cultural, religious and linguistic differences are seen as an asset rather than a reason for exclusion, discrimination or imposed assimilation - as has happened in history too many times. Diversity is assigned an educational value and it is seen as representing a valuable educational opportunity in contemporary complex societies. Disseminated during the last 25 years through continental Europe in particular, this perspective has qualified in an important and consistent manner about twenty years of Italian educational politics and policies. In Italy, the rights of non Italian pupils were upheld by the 1998 Immigration Act that affirmed "the principle of equal treatment for foreigners in access to public services" and placed the "duty on 'regions, provinces, municipal authorities and other local authorities' to take measures aimed at eliminating obstacles" (ENAR Report, 2007). More recently, the Curricular Indications published last year (MPI, 2007), after having underlined that a pupil is a unique individual also because of his/her cultural identity, recommend that dialogue on, and valorization of, different religious beliefs and cultural ways be promoted in heterogeneous classrooms. These new, other, students will "open new horizons" for their Italian peers (and hopefully for their teachers as well) precisely thanks to their diversity. The latter is presented as uncharted territory to be explored and appropriated by as yet unaware Italian students whose minds and hearts will be touched by the encounter with diversity. But it is also envisaged that in learning to understand others' diversity, they will also engage in listening to, and reflecting on, their own feelings of surprise and/ or concern so as to realize how important a disposition towards dialogue and 
interrogation is for the construction of their own identity (idem).

From the beginning, in Italy as elsewhere, intercultural education has been assigned the task of promoting a sense of educational and social membership in their new environment among immigrant students (or immigrants' children), and has been defined as an effective alternative to assimilation and to the construction of bounded ethnic communities - which, however, are increasingly more numerous and visible in most multicultural societies. Towards these two ends, in Italy, for instance, heterogeneous classrooms have ideally been seen as a viable, and equitable, educational decision ${ }^{3}$.

It must also be mentioned that, at least for my country, the twenty year long commitment to intercultural education subscribed to by many teachers and citizens has not been able to effectively ensure the right to education of the non Italian or foreign students (as they are alternatively defined) ${ }^{4}$ (Comitato oltre il razzismo, 2006; Demartini, Ghioni, Ricucci, Sansoé, 2008, for an extensive case study of Turin schools). Firstly, the official regulation of enrolling foreign students in the grade corresponding to their age is not always honoured, and these students' delay in enrolment increases significantly with age and school grade and level, indicating a partial inability to meet these students' educational needs by the schools (MPI, 2008). Secondly, the risk of strengthening and disseminating stereotypical views of other cultures, and of ignoring the interesting changes within those groups, is a matter of real concern, which has been stressed by ethnographic research among Roma, Sinti, Caminanti (Piasere, 2007; Saletti Salza, 2007, 2008; Sidoti, 2007), and among occupational nomads (Gobbo, 2007a, 2007b). It must also be admitted that with time cultural, ethnic and religious diversity seems to have become perceived and treated mainly in terms of limited language proficiency ${ }^{5}$. In any case this prevailing current concern has played down the educational and civic relevance of the goal of learning - all together - that one's own and the other's familiar views of the social and cultural worlds they inhabit could become much wider. In other words, by setting the task of language learning in isolation from the parallel transformation of the other pole of the relation - that is, us - the message is conveyed that far from capitalizing on the opportunity to look into different mirrors, we can keep our gaze fixed on ourselves, and thus avoid learning anything

3 However, it is known that many Italian families choose to enrol their children in primary and lower secondary schools where the number of Roma and foreign pupils and students is low, because the presence of the latter is seen as causing teaching to slow down in order to help those whose linguistic proficiency is limited (Gobbo, 2000).

4 The fact that more and more immigrants' children master Italian language and cultural ways because they were either born in Italy or arrived there at an early age, thus attending Italian schools from the beginning, has prompted the definition of them as either "second generation" or "generation $1.75,1.5$ " in relation - in this case - to the time of their arrival. On the other hand, the legal status of the so called "second generation" youth is that of foreign citizens, and though change of the citizenship law (still based on the jus sanguinis) is presently debated, such change is not yet in sight.

5 Teaching Italian is considered as something that will give the students a passport to social and cultural inclusion, but the way language learning is conceptualized appears rather narrow (Sansoé, 2007) 
different about ourselves. As I pointed out some time ago, this recent trend could probably have already been foreseen when diversity was initially elaborated as the educational resource it can certainly be. However, if we imagine it "as a rather fixed, homogeneous (immigrants seem to have an ethnic identity not a class one!) and unchangeable quality", then even the best educational intentions run the risk "of supporting those very stereotypical attitudes and actions that interculture was meant to challenge" (Gobbo, 2004a, p. 1). Learning about the others' different beliefs, values and behaviour might be necessary though not sufficient if it does not "translate into an ability to consider the hosts' own beliefs, behaviours and habits as similarly situated in culture, ethnicity (if any) and religion. Instead, they are taken as givens, and even considered in danger of being changed, or only challenged, by the others" (ibidem).

For this reason, the crucial role that imagination can play in education, and, increasingly, in our multicultural societies, should be recognized, as has been indicated by philosophers (see, among others, Greene, 1978, 1995; Hanson, 1986; Appiah, 1996; Nussbaum, 1997), and as results from analysis of metaphors of social and cultural heterogeneity (Gobbo, 2009, in press).

\section{"Learning from others" and comparative education}

Before speaking more extensively about fieldwork I would like to consider the importance of "learning from others" in comparative education.

Although the reflective turn that qualifies part of the contemporary educational discourse continues to testify that crucial insights can be reached by going inwards, into a person's experiential dimension as long as it is interpreted - that is, drawn out - through a theoretical perspective, it is true that a greater part of the contemporary educational discourse chooses to outline teaching and learning paths that can answer the challenge posed by globalization. When educators look at schools, teachers and learners from the point of view of the global market, their stress is on efficient teaching of the necessary competences as well as on the awareness that learning must become a lifelong endeavour.

Globalization has spurred school reforms that owe much to the belief upon which comparative education was established as a field of scholarly research: namely, that "learning from others", comparing educational policies and systems, and borrowing, or being lent, reforms could bring improvement to a country's processes of schooling, at the organizational, pedagogical and content level. Furthermore, by upholding the comparative approach, educators and policy makers who travelled to different countries and visited different school systems explicitly recognized the limits of institutional self-sufficiency, perhaps even the dangers of ethnocentric or nationalist pride. They were instead convinced that to collect and disseminate the "lessons from elsewhere" could widen, as it does today, the cultural and socio-political horizon of a country.

From a historical-disciplinary point of view, the others from whom to learn were not individuals, but school systems and institutions, educational strategies and 
innovations, though the so-called end products - the individuals who had been through the learning process - were evidence of a desirable way in which the goal of educational success could also be achieved at home, since it had been achieved elsewhere. What was to be transferred, or transplanted, into new educational soil was chosen on the basis of positive performance and overall results, and though comparative educators soon started to realize that local socio-political contexts and educational traditions had to be taken into account when making their comparisons, the past examples of educational borrowing or lending represented also an opportunity to understand - as Sadler had suggested more than a century ago - the relevant connections, as well as their differences, that various educational perspectives, pedagogical strategies, political and institutional decisions on education could have.

From today's vantage point, could we define those inter-educational encounters as an early form of globalization? In a recent short text, Thomas Popekwitz has in fact argued that there is more to globalization than the economic and social changes for which it is either invoked or rejected, and has thus located globalization much earlier in time that we would have expected. According to his interpretation, globalization emerges in relation to the role of knowledge in modernity: the "disenchantment" that knowledge brought with itself has contributed in a major way to constructing a world inhabited by individuals that are both agents and actors. In Popekwitz's view, the agency exercised by modern individuals has been enacted in history through what he calls "salvation themes", mainly grounded on reason and rationality, that were instrumental in freeing people from the boundaries of their communities of origin and the socio-cultural constraints that they implicate. From this angle, globalization is appropriately defined as a series of "projects of a modern mind that knows itself through particular expert systems of knowledge" (Popekwitz, 2004, p. viii), while it could be added that "border crossing" too began much earlier than we thought! But then, as a researcher, and not unlike my colleagues in education and/or social sciences, I have learned to use theoretical frameworks elaborated elsewhere to explore current problematic issues. In any case, Popekwitz's interpretation lets us clearly understand why the circulation of knowledge was, and is, so crucially connected to the investment in learning/ schooling, whose extension and improvement can in turn question, improve and/ or re-create knowledge.

Not surprisingly, in times of wide socio-political transition or change such as the contemporary one, the relevant "lessons from elsewhere" are brought home by politicians and educators aiming to ameliorate and/or change national educational systems and standards so as to meet the resistible causes of globalization, and to participate in the growing "global interconnectedness". Yet it is worth remembering how historian Tilly interprets the circulation of knowledge and goods we now call globalization, and the consequences that affect some populations but not others. He does so by stressing that "seen from the centres of influence, it looks as though the entire world is globalizing. Seen from the edges, penetration of global influence is highly selective. At least in the short and medium run, it increases 
inequalities. Scientific advances, for example, are having profound effects on medicine, communications, agriculture, and manufacturing. But those effects concentrate very heavily in already rich countries" (Tilly, 2004, p. 20). To this, he then adds that "many of the same unequal connections that transferred wanted goods and services across the world also delivered commodities that few people desired. Global warming provides an obvious example. (...) So far, rich industrial countries have contributed most to global warming through exhaust from their factories, houses, buildings, and motor vehicles. But because poorer industrializing countries generally consume higher-emission fuels, the balance is changing" (idem, p. 21).

Comparative educators, therefore, have become less optimistic about global educational borrowing and lending, and tend to pursue their research goals by paying greater and deeper attention to how contexts with relatively or widely different social histories and cultural institutions may accommodate educational innovation from elsewhere. They also point out that seldom are the latter transferred without being first translated into, or filtered through, the local educational perspectives and traditions (Steiner- Khamsi, 2004).

Schriewer and Martines are among those who have interestingly problematized what, and how, can be learned from others: recently they challenged the assumption that the greater communication and transfer taking place among those concerned with improving schools might lead to convergence of educational patterns, contents and structures. On the contrary, through extensive research, they gave evidence that situated educational traditions and contexts are capable of enacting a subdued, but successful, "resistance" to what others have, or would like, to teach them. Furthermore, they highlighted how acceptance of educational innovations is almost always mediated by local political agendas as well as by theoretical perspectives, pedagogical experiences and personal/professional memories (Schriewer \& Martines, 2004). Thus, what often results from such an inter-educational encounter is not only an interesting re-elaboration of a new educational approach, but also the problematization of some aspects of it that have been brought into relief precisely by its transfer into different contexts.

\section{"Learning from others and with others": the case of ethnographic research, or fieldwork}

I have always believed, and written, that teachers too would benefit from learning to exercise their ethnographic "sight" (Gobbo, 2000, 2004a, 2004b). It is an anthropological mantra that such "sight" places what is familiar to us at a distance, and does the opposite with what is foreign. Some teachers with whom I worked to test a strategy of cooperative learning spelled this out clearly, when they noticed looking at themselves - that we try to understand others, and even ourselves, when we can no longer take the habitual ways of life for granted. It is at that point that it is crucial, and often urgent, to make sense of a situation, of its changes, and to compare the customary way of doing things with a different, or alternative one. 
Ethnographic research or fieldwork has been consistently hailed as a disciplinespecific approach that is also an experience or perhaps more precisely an experiment in experiential learning. Often it has been described as an impressive learning process implicating an indispensable closeness to others - "vivere con" (to live together with), as Italian anthropologist Piasere (2002) has dubbed it, or "intimate, long-term acquaintance" (Wolcott, 1995).

Usually, fieldwork is also defined as participant observation: the stress is on seeing, and on the ethnographer's visual attention. This definition is in line with the many visual metaphors used in cultural anthropology and anthropology of education in order to speak of culture: it is common to speak and write of cultural perspective, mirrors and lenses, of people's point of view and of their world vision, though today we steer away from any panoptic temptation we might have had in the past. However the warm, and metaphorical, invitation that anthropologists issue to their readers and students is that of educating themselves to see, and to avoid "cultural blindness" especially when research is carried out within the researcher's own social environment (Nesbitt, 2004). Anthropologist Harry F. Wolcott reminds us that fieldwork should be "an approach that keeps humans always visibly present, researcher as well as the researched" (Wolcott, 1995, p. 15, emphasis mine). They are visible in a way that to him requires an artist's imagination as well as that of a scientist's, because the fieldworker's task is to reveal something of the other that is already present but still covered or hidden. Thus it is not by chance that Wolcott evokes Michelangelo and his theory of sculpture through a story attributed to the artist: "when asked to describe how he carved the magnificent David, his explanation was, 'I took a block of stone and chipped away everything that was not David'. His famous set of statues - the anthropologist continues - the Prisoners of Stone, suggests something of the same. Once the figures were freed, Michelangelo did not return to 'complete' the works; his task was finished, in spite of the fact that the statues were not" (idem, p. 27).

For his part, Italian anthropologist Piasere notices that in doing ethnographic research it is impossible to distinguish neatly between ethnographer and subjects of research: in fieldwork, the one becomes part of the field, as the other is by definition. But in this case, the sense of sight is no longer the prevailing one: the ethnographer's participation or immersion in the field implies that all the senses are engaged. Yet, I believe that with multiculturalism and its demand that the others' voice be listened to - and seriously listened to, as Griffiths states (2003) hearing comes eventually to the foreground, qualifying the others as speakers, spokespersons, or interlocutors who must not only be observed but also asked and (seriously) listened to. From being subjects (or worse, objects) of research, the others, from whom ethnographers wish to learn, become their interlocutors and collaborators in the success of the project. As has been remarked (see Galloni, 2007; Gobbo, 2007b), the others do not merely listen and answer the researcher's questions, but they themselves ask him/her questions, make observations, or keep silently to themselves (Piasere, 1997). For his part, the ethnographer recognizes that "fieldwork is characterized by personal involvement to achieve some level of 
understanding that will be shared with others" (Wolcott, 1995, p. 66), and that "in the simple act of asking, the fieldworker makes a 180-degree shift from observer to interlocutor, intruding into the scene by imposing onto the agenda what he or she wants to know" (idem, p. 102).

For us educators, the idea of learning that anthropologists share appears somewhat eccentric: while it is acknowledged that the subjects of research are their teachers, the latter never speak ex cathedra, even though they are the only ones to possess the relevant information which anthropologists are eagerly looking for. The special learner-teacher relationship entailed by ethnography is rather informally enacted, and those teachers hardly pass on their knowledge according to any sort of curricular indications. At the same time, the ethnographer-learner learns by asking questions (and this is also quite different from a regular classroom teaching session) but the questions he/she asks are meant to find out what the others "know and know about, not to 'test' their knowledge. The questions we ask, the manner in which we ask them, and what we do with the information given are intended to signal our interest in and regard for what people know" (idem, p. 107). It is an interest that is not confined to information, though, because ethnographers find it really difficult, if not impossible, to imagine starting a study for which they have "no personal feelings, felt no interest or concern for the humans whose lives touched" theirs (idem, p. 166). As Nesbitt (2004, p. 150) recommends, "ethnography requires us to be reflexive, because the ethnographer affects, and is affected by, the field".

In the end, unforgettable lessons of life are learned from others: "waiting" is one of them, as "we cannot hurry the lives of those about us, but only our own" (Wolcott, 1995, p. 85), and in any case "fieldworkers live with the excitement of continually learning and unlearning, formulating and reformulating pictures of how individuals and groups are connected and how identities evolve, including their own identities" (idem, p. 153), a condition that many educators and teachers would love to see shared by their students as well.

\section{"Learning with others" and cooperative learning}

What about learning with others through cooperative learning? When we talk of learning with others we add a different quality to what I have so far presented: we claim that this kind of learning is not only a collective endeavour whose responsibility is at the same time assumed by the group and by each group member, but also that it is not structured according to that "division of labour" I mentioned earlier and that the teacher-learner pair helps to visualize.

Learning with others blurs instead such distinctions as much as the process of cultural acquisition and the construction of cultural propriospect had blurred the boundaries between cultures (Wolcott, 1996). In this case, learning becomes a task that can be better achieved with others, yet the cooperative task is interpreted as enhancing individual agency and initiative to ask different questions and propose different solutions. The others are the partners, co-workers, co-teachers and colearners with whom to carry out and complete a project, or plan how to solve a 
problem. Going beyond individual success aims at improving classroom relations, at creating a climate that will benefit the single learner as well.

In educational thought, "learning from others and with others" is valued positively because it acknowledges learners as active persons, characterized by a disposition to assume responsibility - as individuals and as group members - for what they accomplish, on the one hand, and on the other hand as persons with different backgrounds and experiences that can bring unexpected views and contributions to school work and be seen as pupils or students "of promise" rather than "at risk". In my view, this does not so much entail celebrating diversity as noticing, and enhancing, what becomes relevant and meaningful in connection with time, social and personal relations, communication modes and competences. Diversity certainly cannot exist without being acknowledged and respected by others, but at the same time it requires the creation of an educational environment and opportunities that can effectively realize the right to education for everyone. "Learning from others and with others" can thus become a transformative experience - that is, an authentic educational experience - because it entails the acquisition of knowledge that concerns both school learning and ourselves as situated selves, as differently enculturated persons.

And yet, if I were to stop at this point, and congratulate educators for having devised a desirable educational strategy to overcome selfish behaviour and goals, or at least to tame them so as to later transform them in capacities for collaboration and respect, I could certainly be satisfied from an ideal and normative point of view, but I would become aware that a few important aspects - such as the classroom context and the web of social expectations - have remained bracketed out of the picture.

Educationally important as cooperative learning is, to practise it as if it were mostly a matter of changing the rules of the learning game would not make us, and others, able to confront diversity as an issue pertaining to the discourse of social justice ${ }^{6}$. This last part of my presentation is devoted to a certain way of thinking, and then of engineering, how cooperation can bring about equity, and not only a safe, friendly classroom climate. Complex Instruction, invented by the late sociologist and educator Elizabeth Cohen, is not only interesting as group work, but has also the major quality of indicating how established social expectations and habitual classroom tasks can confirm what she defines as classroom and social stratification.

Her main goal being the achievement of equitable classrooms ${ }^{7}$, Cohen warned

6 While the many versions of cooperative learning are presented as all aiming to realize more effective opportunities for everyone to learn and participate in the educational process, it seems that those different versions of cooperative learning focus more (and certainly understandably) on how to work in group or cooperatively, and less on how students' social and cultural differences (and their perceived social status) can prevent the attainment of such goal. See Batelaan P. \& Van Hoof C. (1996) and Batelaan P. (1998).

7 As she wrote, "the purpose of the program is the creation of equitable classrooms. These are classrooms where all students have access to challenging curricula, where students all participate equally in cooperative learning, helping each other to grasp difficult concepts and to solve 
that re-organization of classroom work would not be enough to pursue social justice. Those pupils and students who are perceived as others in a negative sense can be formally included in a group, but at the same time be successfully excluded from interaction and thus from learning. She urged teachers and educators to understand the structural and cultural reasons why diversity and exclusion go together even in situations where the opposite is purposefully aimed at. Thus her Complex Instruction is logically preceded by the sociological analysis of the social system of the classroom that is characterized by a certain kind of classroom task, by the roles of the students and teachers, and by the patterns of interaction among students and between students and teachers.

What are the forces outside and inside the classroom that create inequity among students and that we need to understand in order to create equitable classrooms? I will concisely indicate them, and then proceed to share what I learned from the teachers and with the teachers engaged in testing their own didactic unit of Complex Instruction.

According to Cohen (2003), the structural conditions that influence classroom interaction and learning are to be found in the social conditions that result from wide changes in populations' movements and diversity. They can be summarized as the following:

- growing population heterogeneity,

- growing school population heterogeneity,

- limited language of instruction proficiency,

- marked cultural differences with respect to mainstream culture.

Social stratification also takes its toll, as it produces

- cultural differences related to socio-economic differences,

- low socio-economic status,

- lower political and economic resources,

- discrimination/exploitation/exclusion,

The consequences inside the classroom and in school work are such that the divide between successful and unsuccessful pupils and students is strengthened. In fact, exclusion is very likely to take place when some students

- are expected to be unable to learn both basic and higher order concepts,

- do not have equal access to interesting learning materials,

- are not expected to be ready for tasks requiring a higher order cognitive capacity,

- cannot participate in group work in an active and significant way, and

- their ideas are not taken into consideration by their peers.

The classroom social system is furthermore characterized by language and cultural differences connected to individual differences,

problems, and where almost all of the students are successful in academic performance". (Cohen, 2003, p. 15). 
- initial learning differences,

- different cultural repertoires,

- that all contribute to the formation of

- different expectations of learning competence, and

- differences in academic status and in peer status

The latter are the consequences of different expectations of learning competence by teachers and peers because of the non-diversified character of school learning activities, since

- tasks are the same for every students,

- students cannot decide how to carry out the task,

- teacher's evaluation criteria are usually the same for every student's work,

- students cannot evaluate their own work,

- an academic hierarchy among students and a difference in academic status among peers are established.

Cohen paid close attention (and invited teachers to do the same) to how interaction among students and between students and teachers is related to learning, noticing that the higher status students are those who interact more often and thus learn more. Her conclusion addressed the reasons why inequality may persist in group work participation, namely i) status problems, ii) students' self-perception, iii) students' perception of other, low status students, iv) local academic and peer status problems, v) different expectations of competence, that taken all together are at the basis of self-fulfilling prophecies. The didactic strategy she invented consists of didactic units centred on multiple abilities, and expects teachers to delegate authority to pupils and to give detailed feedback to them on group work dynamics, once the tasks have been completed. As I wrote, "though Complex Instruction predates intercultural education, it has a powerful intercultural dimension since it looks at, and works with students' different cultural, linguistic and cognitive abilities as resources for a form of learning that is achieved when every student participates equally in group work, and can contribute in his/ her specific way to the understanding of difficult concepts and to the solution of open-ended problems" (Gobbo, 2007c, p. 77) ${ }^{8}$.

Up to this point, I have spoken of cooperative learning as an educational strategy enacted by highly motivated teachers - in Italy and elsewhere - who aim to make pupils and students understand that there are different ways to learn, and that some of these ways can be more just than others, when each is made responsible

8 With regard to the this point, Pieter Batelaan' writings and projects were crucial in establishing the connection between intercultural education and cooperative learning - and Complex Instruction in particular - and to disseminate it in Europe through the International Association for Intercultural Education (IAIE), the conferences it promoted, and the articles in the European Journal of Intercultural Studies (now Intercultural Education). Gent Steunpunt ICO in Flemish Belgium was equally important and often worked in conjunction with Pieter Batelaan and IAIE towards the same educational and innovative aims. See Batelaan P. (1998). 
not only for his or her performance but also for that of his/her classmates. This does not mean that "learning with others" is always successful or unproblematic: on the contrary, I want to suggest that the above indicated educational and civic goals are met when the understanding of what a cooperative learning project requires is accompanied by teachers' social and cultural self-questioning and conjecturing. Their efforts of analysis and interpretation may eventually become a true learning experience for all.

During the meetings, when teachers prepared and discussed the didactic unit to be tested, they realized how they had also learnt to relate to their pupils and themselves as classroom ethnographers (see Gobbo, 2007c). In their reflective narratives, those teachers initially brought the relevance of their own civic and educational values, as well as of their own political and educational experience, to the foreground, making all of us understand that perhaps another kind of "lesson from elsewhere"had been learned while they practised Cohen's cooperative learning strategy. By comparing and discussing with each other what had happened in their classrooms, and had left them with a feeling of uneasiness, they were then able to cast a critical look at the so called "culture of the school" and the expectations and behaviour that make it visible, even though it usually remains largely hidden and implicit, at least from a strictly educational perspective.

Teaching teachers this strategy of cooperative learning had been geared to providing them with a new and hopefully effective answer to the structural changes taking place in Italian schools and society as result of immigration flows. In their view, the contemporary migratory processes had caused a new sense of social and educational responsibility as well as an eagerness for educational approaches capable of being creative and effective. That was what they all had expected from the course, and why some of them later continued to meet.

The teachers'awareness could be seen as the result of a special kind of intercultural encounter, that deserved to be explored through reflective conversations in order to understand if, and in what ways, their eagerness to learn and practice educational innovations was in a dialectical relation to their professional experience as well as to their personal value choices and goals.

For one of them, whom I will call Silvia, Cohen's strategy could not only open and problematize "teachers' [current] educational horizons", but also raise issues such as the influence social status has on children's learning, the goal of equality of educational opportunities and the problematic status and role of teachers, back to the current Italian educational scene. Silvia connected her participation in many educational innovative projects to the time when she started to teach: she had colleagues who had been involved in the educational and political "battle" to introduce longer hours of schooling so as to provide children from disadvantaged Italian families with educational direction and support in doing their homework. Her political involvement dated from those years, and she stressed that the seventies and the first years of the new century had many things in common. If

9 For example, a detailed report of what worked and what worked less well can be found in Batelaan P. (1998) with regard to the Comenius Project CLIP that involved nine European countries. 
earlier progressive educational innovations addressed the needs of Italian families, by providing them with tempo pieno (full-time schooling), now the changes have to be answered in new, educationally effective, ways. Her appreciation for the course on Cohen's cooperative learning approach was for an additional, distinct reason, namely the possibility of reaffirming her values, hopes and goals for an education concerned with the common good.

Two others (with the fictional names of Valeria and Elena) also remembered the seventies and the drive in favour of educational changes carried out by the teachers that had characterized those years. Back then, group work had been introduced in classrooms, and teachers' authority had been questioned through so called active pedagogies that entailed teaching pupils and students how to do research in their familiar environment, write reports on the data collected, and even prepare their own textbooks together with the teacher. The fourth teacher acknowledged that to her the Complex Instruction's focus on social justice and equality of education was ideally connected to the students' and country's unrest of 1968. She was still in high school, at the time, but it seemed that those conflict-ridden years had left in her the determination to find, and put into practice, "principles and tools to create a friendlier and more tolerant climate among pupils".

With their sharp and articulate reflections on themselves as persons and as professionals, on their educational ways and the school environment, this small group of teachers provided a special educational contribution, besides producing their own Complex Instruction unit and testing it in their own classrooms of Bologna city and province. Practicing Complex Instruction in classrooms with children between 6 and 10 years of age made them realize that, perhaps not surprisingly, they had taken for granted the way things are usually done in school, or, better, that had looked at those ways from an exclusively educational point of view - what they aimed at, rather than how they aimed at it. However, once they started to organize cooperative class work around the units they themselves had created, this didactic turn helped them to see that their sincere enthusiasm for implementing innovation had initially obscured important aspects that deserved examination. For instance, there was the "culture(s) of the school" - the way their work is characterized by a specific, but largely common, way of teaching and organizing learning activities that also influenced their interaction with pupils and the latter's expectations. One of these teachers, for instance, had realized that it was really hard for her to let pupils succeed, or fail, by themselves, while they were working on the cooperative learning units. Increasingly uneasy, and aware that hovering over the pupils working in groups had been advised against by Elizabeth Cohen, that teacher had eventually interpreted her anxious behaviour through her habit of mediating learning and answering pupils' many questions and requests for help.

The same teacher also looked for further explanations, hypothesizing that institutional pressure not to waste school-work time, and to use it in the most efficient way, was somewhat responsible for her "inappropriate" behaviour. She remarked that to explain to pupils how to go about carrying out a task or 
solving a problem, saved her some time. Thus having seldom asked them to read the instructions by themselves, she could now understand why her pupils were troubled by the new requirement.

I have summarized those teachers' narratives not to argue that learning and practising cooperative learning is a walk down "nostalgia lane", but rather to point out what educational comparativists have alerted us to, namely that any innovation is mediated, or filtered, through local theoretical perspectives and pedagogies. In this particular case, testing the units of Complex Instruction in their classrooms also gave those teachers the occasion to re-affirm, update and even re-invent educational goals that they had strongly supported, and still support and identify with.

\section{Conclusions}

As an educator and an anthropologist of education I am well aware that the historical turn of multiculturalism, about forty years ago, resulted in research and theorization specifically conducted on processes of acquisition of knowledge - that is learning - as they were allowed to focus on and to interpret cultural diversity, also and particularly within social groups, differently from the focus on cultural transmission. The cultural "propriospect" theorized by Goodenough (1976) and Wolcott (1996) aimed precisely at pointing out how different social, historical and political circumstances influence learning, so that what we learn is always mediated by what we already learned (in the family, in the group, in the environment), or have had a chance to learn independently.

Of course, those processes of cultural and educational exploration and acquisition do not always result in a positive educational experience: from others we might learn prejudices or ways to exclude peers from sharing tasks and knowledge. As for working in groups - and thus not only learning from others but also with others this does not always guarantee inclusion and cooperation, as I have just indicated in the previous paragraph. The celebration of diversity (that, among other things, aims at maintaining or raising pupils' self-esteem) too often ignores the social, political and economic reasons why diversity has come to stay - especially if it concerns immigrants' and minorities' diversity. For these reasons I believe that Elizabeth Cohen's warning should still be heeded: when teachers (as well as innovative educators) fail to recognize that they perceive negatively the connection between diversity and low social status (due to social or ethnic stratification), they also fail to acknowledge how the resulting low expectations will significantly limit their interaction with the low status pupils, as well as the interaction between the latter and high status students. The consequence will be that the goal of constructing equitable classrooms through learning from each other in groups will be severely limited if at all attained. 


\section{References}

Anderson, B. (1996). Comunità immaginate. Origini e diffusione dei nazionalismi. Roma: Manifestolibri (or. ed. 1983).

Appiah, K. A. (1996). Race, Culture, Identity: Misunderstood Connections, In K. A. Appiah \& A. Gutmann (Eds.), Color Conscious. The Political Morality of Race (pp. 30-105), Princeton: Princeton University Press.

Barth, F. (Ed.) (1969). Ethnic Groups and Boundaries. The social Organization of Culture Difference. Boston: Little, Brown \& Co.

Batelaan, P. (Ed.) (1998). Towards an equitable classroom. Cooperative Learning in Intercultural Education in Europe. Meppel, NL: IAIE, Drukkerij Giethoorn Ten Brink.

Batelaan, P. \& Van Hoof, C. (1996). Cooperative learning in intercultural education, European Journal of Intercultural Studies, 7(3), 5-16.

Beattie, J. (1964). Other Cultures. Aims, Methods and Achievements in Social Anthropology. New York: The Free Press.

Benveniste, E. (1976). Il vocabolario delle istituzioni europee. Torino: Einaudi (or. ed. 1969).

Berland, J. C. \& Salo, M. T. (1986). Peripatetic Communities: An Introduction. J. C. Berland \& M. T. Salo (Eds.), Peripatetic Peoples, special issue of Nomadic Peoples, no. 21-22, pp. 1-6.

Berube, M. R. (1994). American School Reform. Progressive, Equity, and Excellence Movements, 1883-1993. Westport Conn: Praeger.

Bohannan, P. (1998). Asking and Listening. Ethnography as Personal Adaptation. Prospect heights, III: Waveland press.

Coetzee, J. M. (2000). Aspettando i barari. Torino: Einaudi. (or. ed. 1980).

Cohen, E. G. (2003). Equità, scuola e Istruzione Complessa: i principi di base. In F. Gobbo (Ed.). Multiculturalismo e intercultura. (pp. 153-178). Padova: Imprimitur Editrice.

Comitato oltre il razzismo. (2006). Concentrazionee dispersione differenziale degli allievi stranieri nelle scuole di Torino. Available at: http://www.piemonteimmigrazione.it

Demartini, M., Ghioni, J., Ricucci, R., \&Sansoé, R. (2008). Gli allievi stranieri come banco di prova: il caso Torino. In F. Gobbo (Ed.) L'educazione al tempo dell'intercultura. (pp. 129-146). Roma: Carocci.

Ecotec. (2008). Study on the school education of children of occupational travellers in the EU. Final Report to the Directorate General for Education and Culture of the European Commission. Birmingham.

European Commission. (1994). Report on the education of migrants' children in the European Union. Luxemburg: Office for Official Publications of the European Communities.

European Network Against Racism (ENAR). (2007). Fighting racism and promoting equal rights in the field of education. Brussels: ENAR.

Florio-Ruane, S. (1996). La cultura e l'organizzazione della classe scolastica, In F. Gobbo (Ed.) Antropologia dell'educazione. Scuola, cultura, educazione nella società 
multiculturale. (pp. 171-189). Milano: Edizioni Unicopli. (or. ed. 1994).

Galloni, F. (2007). Etnografia: scelta metodologica e non solo. In F. Gobbo (Ed.) La ricerca per una scuola che cambia. (pp. 21-68). Padova: Imprimitur Editrice.

Gobbo, F. (1977). Decentramento e partecipazione di base: il caso della Black america, Scuola e Città, XXVIII, 1, 32-39.

Gobbo, F. (1992). Radici e frontiere. Contributo all'analisi del discorso interculturale. Padova: Editrice alfasessanta.

Gobbo, F. (2000). Pedagogia interculturale. Roma: Carocci.

Gobbo, F. (2003). C'è una giostra nel futuro? Esperienza scolastica e processo di inculturazione in una minoranza occupazionale nomade. In F. Gobbo (Ed.) Etnografia dell'educazione in Europa. Soggetti, contesti, questioni metodologiche. (p. 209-245). Milano: Edizioni Unicopli.

Gobbo F. (2004a), "Ethnographic Research as a Re/Source of Intercultural Education”, in Proceedings of INST International Conference "Das Verbindende der Kulturen" (Vienna, november 2003), http://www.inst.at/trans/15Nr/08 1/gobbo15.htm, pp. 1-12.

Gobbo, F. (2004b). L'insegnante come etnografo: idee per una formazione alla ricerca. In G. Favaro \& L. Luatti (Eds.) L'intercultura dalla A alla Z. (p. 126-135) Milano: FrancoAngeli.

Gobbo, F. (2006). Along the Margins, Across the Borders: Teaching and Learning among Veneto attrazionisti viaggianti. In Antelitz, Coombes \& Danaher (Eds.) Marginalised Pedagogues? International Studies of the Work and Identities of Contemporary Educators Teaching 'Minority' Learners", special issue of Teaching and Teacher Education, 22 (7), p. 788-803.

Gobbo, F. (2007a). Alunni 'di passo'? Le narrazioni degli insegnati sulla scolarizzazione dei figli degli attrazionisti viaggianti. In F. Gobbo (Ed.) Processi educativi nelle società multiculturali: percorsi di ricerca etnografica. (p. 139-159). Roma: CISU.

Gobbo, F. (2007b) Between the road and the town: the education of travelling attractionists. An ethnographic research. In W. T. Pink \& G.W. Noblit (Eds.) International Handbook of Urban Education. (p. 481-503) Dordrecht: Springer.

Gobbo, F.(2007c).Teaching teachers cooperativelearning: an intercultural challenge. In G. Bhatti, C. Gaine, F. Gobbo, \& Y Leeman (Eds.) Social Justice and Intercultural Education: an open-ended dialogue. (p. 75-88). Stoke on Trent: Trentham Books.

Gobbo, F. (2009). On metaphors, everyday diversity and intercultural education, Intercultural Education (in press).

Goodenough, W. H. (1976). Multiculturalism as the Normal Human Experience, Anthropology and Education Quarterly, 7(4), 4-7.

Greene, M. (1978). Landscapes of Learning. New York: Teachers College Press.

Greene, M. (1995). Releasing the Imagination. Essays on Education, the Arts, and Social Change. San Francisco: Jossey-Bass.

Griffiths, M. (2003). Action for Social Justice in Education. Maidenhead, UK: Open University Press.

Hanson, K. (1986). The Self Imagined. Philosophical Reflections on the Social Character of Psyche. New York: Routledge \& Kegan Paul. 
Ministero della Pubblica Istruzione (MPI). (2007). Indicazioni per il curricolo per la scuola dell'infanzia e per il primo ciclo dell'istruzione. Roma: MPI.

Ministero della Pubblica Istruzione (MPI). (2008). Alunni con cittadinanza non italiana. Scuola statali e non statali. Roma: MPI.

Nesbitt, E. (2004). Intercultural Education. Ethnographic and Religious Approaches. Brighton: Sussex Academic Press.

Nussbaum, C. (1997). Cultivating Humanity. A Classical Defence of Reform in Liberal Education. Cambridge, (MA): Harvard University Press.

Ogbu, J. U. (1996). Educazione e stratificazione sociale. In F. Gobbo (Ed.) Antropologia dell'educazione. Scuola, cultura, educazione nella società multiculturale. (p. 113126). Milano: Edizioni Unicopli Editore. (or. ed. 1994).

Piasere, L. (1997). Etnografia Romaní, ovvero l'etnografia come esperienza. In F. Gobbo (Ed.). Cultura Intercultura. (p. 35-80). Padova: Imprimitur Editrice.

Piasere, L. (2002). L'etnografo imperfetto. Esperienza e cognizione in antropologia. Roma-Bari: Laterza.

Piasere, L. (2004). La sfida: dire 'qualcosa di antropologico' sulla scuola. In L. Piasere L. (Ed.). Scuola, numero speciale di Antropologia, 4 (4), 7-17.

Piasere, L. (2007). Rom, sinti e camminanti nelle scuole italiane. Risultati di un progetto di ricerca di etnografia dell'educazione. In F. Gobbo (Ed.) Processi educativi nelle società multiculturali. (p. 161-172). Roma: CISU.

Popekwitz, T. S. (2004). Foreword. In G. Steiner-Khamsi (Ed.) The Global Politics of Educational Borrowing and Lending. (p. vii-xi). New York: Teachers College Press.

Saletti Salza, C. (2003). Bambini del "campo nomadi". Romá Bosniaci a Torino, Roma: CISU.

Saletti Salza, C. (2004). La gestione del quotidiano scolastico di alunni rom, Quaderni di sociologia, XLVIII (36), 7-29.

Saletti Salza, C. (2007). Frequenza e profilo scolastico degli alunni rom xoraxané bosniaci domiciliati a Torino. Un confronto tra etnografia e ricerca quantitativa. In F. Gobbo (Ed.) Processi educativi nelle società multiculturali. (p. 173-189). Roma: CISU.

Saletti Salza, C. (2008). Alunni rom e sinti, soggetti di un percorso 'speciale', differenziante. In F. Gobbo (Ed.) L'educazione al tempo dell'intercultura. (p. 109128). Roma: Carocci.

Sansoé, R. (2008). Figli dell'immigrazione: nati da famiglie immigrate e cresciuti nella scuola italiana. In F. Gobbo (Ed.) La ricerca per una scuola che cambia. (pp. 115-140) Padova: Imprimitur Editrice.

Sartre, J.-P. (1990). La nausea. Torino: Einaudi. (or. ed., 1938).

Schriewer, J. \& Martines, C. (2004). Construction of Internationality in Education. In G. Steiner-Khamsi (Ed.) The Global Politics of Educational Borrowing and Lending. (p. 29-53). New York: Teachers College Press.

Sidoti, S. (2007). Scuole possibili. Lungo la strada dei caminanti di Noto. In F. Gobbo (Ed.) Processi educativi nelle società multiculturali. (p. 191-207). Roma: CISU.

Steiner-Khamsi, G. (Ed.) (2004). The Global Politics of Educational Borrowing and Lending. New York: Teachers College Press. 
Tilly, C. (2004). Past, Present and Future Globalizations. In G. Steiner-Khamsi (Ed.) The Global Politics of Educational Borrowing and Lending. (p. 13-28). New York: Teachers College Press.

van Zanten-Henriot, A. (1996). Le relazioni tra scuola e comunità. In F. Gobbo (Ed.) Antropologia dell'educazione. Scuola, cultura, educazione nella società multiculturale. (p. 147-157). Milano: Unicopli Editore. (or. ed. 1994).

van Zanten, A. (2003). 'Studenti seri' e 'studenti turbolenti': ordine e disordine nelle scuole medie della periferia francese. In F. Gobbo (Ed.) Etnografia dell'educazione in Europa. (p. 51-77). Milano: Edizioni Unicopli.

van Zanten, A. (Ed.) (2000). L'école, l'état des savoirs. Paris : Editions de la Découverte.

Wax, M. L. \&Wax, R. H. (1971). Great Tradition, Little Tradition, and Formal Education. In M. L. Wax, S. Diamond, \& F. O. Gearing (Eds.) Anthropological Perspectives on Education. (p. 3-18). New York: Basic Books.

Wolcott, H. F. (1995). The Art of Fieldwork. Walnut Creek: Altamira Press.

Wolcott, H. (1996). Trasmissione e acquisizione culturale. In F. Gobbo (Ed.) Antropologia dell'educazione. Scuola, cultura, educazione nella società multiculturale. (p. 49-64). Milano: Edizioni Unicopli. (or. ed. 1994). 